\title{
2 Programmed Death of Injured Pseudomonas \\ 3 aeruginosa on Mechano-Bactericidal Surfaces
}

\author{
4 Shuo Zhao ${ }^{1}$, Zheyu Li ${ }^{1}$, Denver P. Linklater ${ }^{2}$, Lin Han ${ }^{4}$, Peng Jin ${ }^{4}$, Liping Wen ${ }^{5}$, Chuan \\ 5 Chen $^{1}$, Defeng Xing ${ }^{1}, N_{a n q i}$ Ren $^{1}$, Kai Sun ${ }^{1 *}$, Saulius Juodkazis ${ }^{3}$, Elena P. Ivanova ${ }^{2 * *}$, Lei \\ 6 Jiang $^{5}$
}

7 1. State Key Laboratory of Urban Water Resources and Environment, School of

8 Environment, Harbin Institute of Technology, Harbin, 150090, China

9 2. School of Science, RMIT University, Melbourne, VIC, 3000, Australia

3. Optical Sciences Centre, Swinburne University of Technology, Hawthorn, VIC, 3122 , Australia

4. Key Laboratory of Micro-systems and Micro-structures Manufacturing (Harbin Institute of Technology), Ministry of Education, Harbin 150080, China

5. Technical Institute of Physics and Chemistry, Chinese Academy of Sciences, Beijing 100190, China. 


\section{Experimental Section}

1.1. Black silicon fabrication and characterization

1.2. Antibacterial Assays: flow cytometry and plate count

1.3. Fluorescent microscopy

1.4. Morphology investigation

1.5. Process of in-situ diluting for testing the influence of pipetting to the bacteria

2. Supplementary results

Figure S1: Plate count photographs in lower cell density

Table S1: 6 h Plate count results in higher cell density

Figure S2: Cell density characterization of the retrieved suspension

Figure S3: Flow cytometer plots of positive control for Live/Dead test

Figure S4: Flow cytometric analysis of bacteria after $6 \mathrm{~h}$ incubation

Figure S5. Fluorescence micrographs of injury analysis for attached cells

Fugure S6: Flow cytometer plots of PS exposure analysis

Figure S7-S9: Fluorescence micrographs of Annexin V/ PI uptake for attached cells

Figure S10: TEM of non-proliferative cells

Figure S11: SEM images of non-proliferative cells on bSi

Figure S12: Fluorescence micrographs for representing the remained bacteria on the surface

Figure S13: TEM images of bacterial cells retrieved from the control surface

Figure S14: Plate count results and Fluorescence micrographs to characterize the influence of pipetting to the bacterial viability

Figure S15: The confirmation of post-stressed bacterial cells cannot be resuscitated by plate count

Figure S16: Flow cytometric analysis of ROS level after longer incubation

Figure S17: The UV-Vis absorption spectrum of the medium with $0.0002 \%$ phenol red indicator

Figure S18. Photos of bSi with $20 \mu \mathrm{l}$ bacterial suspension on their surfaces 


\section{Experimental Section}

\section{1.1. Black silicon fabrication and characterization}

3 The bSi surface was fabricated by reactive ion etching (RIE) (ME-3A, Institute of

4 Microelectronics, Chinese Academy of Sciences). The protocol has been described elsewhere ${ }^{1,}$

$5 \quad 2$. Briefly, the silicon wafer (2", p-type boron-doped, $<100>$, resistivity $10-20 \Omega \mathrm{cm}-1,525 \pm$

$625 \mu \mathrm{m}$,) was sonicated in acetone, methanol and DI water for 5 min subsequently, then soaked

7 in HF to remove the layer of silicon oxide. After rinsing the substrate with water and blowing

8 it dry with nitrogen gas, the silicon wafer was subjected to RIE for $50 \mathrm{~min}$. The flow rates of

$9 \mathrm{O}_{2}$ and $\mathrm{SF}_{6}$ of RIE were set to 36 and $40 \mathrm{sccm}$, respectively, with a chamber pressure of 1035 mTorr and RF power of $100 \mathrm{~W}$.

11 The bSi surfaces were characterized by SEM (ZEISS Sigma500, ZEISS) at an accelerating voltage of $10 \mathrm{kV}$, under high vacuum. XPS (Kratos Axis Nova, Kratos) with monochromatic

$13 \mathrm{Al} \mathrm{K \alpha} \mathrm{X}$-ray source $(\mathrm{h} v=1486.6 \mathrm{eV})$ at a power of at $150 \mathrm{~W}$. The XPS spectra were fit using 14 XPS peak41, and the background was subtracted using a Shirley baseline technique. The 15 hydrocarbon component of the C $1 \mathrm{~s}$ peak (binding energy $285.0 \mathrm{eV}$ ) was used as a reference 16 for charge correction. The surface architecture was analyzed using AFM (Bruker Dimension 17 Icon, Bruker).

\subsection{Antibacterial Assays: flow cytometry and plate count}


2 Collection and stored at $-80^{\circ} \mathrm{C}$. Before each experiment, the strain was revived from stock on

3 nutrient agar for $24 \mathrm{~h}$ at $37^{\circ} \mathrm{C}$. The strain was then incubated in Luria Bertani (LB) broth and

4 cultured overnight at $37^{\circ} \mathrm{C} .5 \mathrm{~mL}$ of bacterial suspension was centrifuged at $4000 \mathrm{rpm}$ for 5

$5 \mathrm{~min}$, and the supernatant was discarded. The bacterial cell pellets were then washed with $5 \mathrm{~mL}$

6 of fresh LB broth. In the end, the suspension was adjusted to the density of $\mathrm{OD}_{600}=0.1\left(4 \times 10^{5}\right.$

7 cells in $20 \mu \mathrm{L}$ of suspension $\left.{ }^{3}\right)$ or $\mathrm{OD}_{600}=5\left(2 \times 10^{7}\right.$ cells in $20 \mu \mathrm{L}$ of suspension $\left.{ }^{3}\right)$ in $\mathrm{LB}$ broth.

8 The bSi and Si wafers (as a control surface) were cut into $15 \mathrm{~mm} \times 15 \mathrm{~mm}$ slides and cleaned

9 with UV-ozone. The surfaces were placed in a sterile 12-well plate (JETBIOFIL). $20 \mu \mathrm{L}$

10 bacterial suspension was added to each surface for incubation at $20{ }^{\circ} \mathrm{C}$. The humidity of the

11 incubator was controlled at $60 \%$, and the plates were sealed by gas permeable parafilm.

12 Incubation times were varied.

\subsubsection{Retrieving and pretreatment for flow cytometry.}

14 After incubation on the slides, $P$. aeruginosa cells in $20 \mu \mathrm{L}$ of inoculating suspension were

15 retrieved by the following process: $200 \mu \mathrm{L}$ PBS was dropped onto the surfaces gently, then the bacteria were pipetted from the surfaces with the PBS. The PBS solution was collected after each rinsing step and fresh PBS was added again. This was repeated for 10 cycles. PBS did not submerge the sample to avoid bacterial cell loss. Particles larger than $10 \mu \mathrm{m}$ were filtered from the suspension. The procedures of the fluorescent labeling and instrument parameters are described in the following subsections and supplementary information.

\subsubsection{Plate count.}



incubating bacteria on the bSi and the Si wafer samples, cells were retrieved as described

3 above. For better counting, the suspension was collected and serially $10 \times$ diluted by $5 \times 10^{6}$

4 times, using PBS $(\mathrm{PH}=7.4)$. After diluting, $1 \mathrm{~mL}$ of each dilution sample was mixed with 15

$5 \mathrm{~mL}$ of $45^{\circ} \mathrm{C}$ nutrient agar and incubated for $48 \mathrm{~h}$ at $37^{\circ} \mathrm{C}$. According to the number of colonies

6 of the experimental group (bSi) and the control group (Si), bactericidal efficiency was

7 determined by the number of colony forming units CFU (bSi) / CFU ( $\mathrm{Si}$ ).

8 1.2.4. Live/Dead.

9 SYBR Green I and PI were used to label live and dead cells, correspondingly ${ }^{5,6}$. All the cells can be labeled by SYBR Green I, but dead cells can also be labeled by PI. When PI is excited, the fluorescence of SYBR Green I will be quenched. Thus, live and dead cells can be identified separately. The surfaces were rinsed 10 times by PBS to ensure all the bacterial cells were collected. The bacterial suspension was adjusted to $1 \times 10^{6}$ cells $/ \mathrm{mL} .2 \mu \mathrm{L}$ of each stain (SYBR Green I and PI, Invitrogen) stock solution ( $1 \mathrm{mg} / \mathrm{mL})$ was added in to $0.5 \mathrm{~mL}$ of the suspension. Bacteria and dye suspensions were incubated for $15 \mathrm{~min}$ in dark. Fluorescence was measured by flow cytometer.

\subsubsection{Analysis of PS Exposure.}

Experiments were performed according to the instructions provided by Alexa Flour 488 annexin V/Dead Cell Apoptosis Kit (Invitrogen). Annexin V labeled with fluorophore has a high affinity for phosphatidylserine (PS) and can identify the PS exposed apoptotic cells. The red-fluorescent propidium iodide is a membrane impermeable nucleic acid binding dye that 
1 labels the dead (non-viable) cells. The cell retrieval procedure was described above. The

2 retrieved cells were washed and resuspend to $1 \times 10^{6}$ cells $/ \mathrm{mL}$ with annexin-binding buffer. 5

$3 \mu \mathrm{L}$ of Alexa Flour 488 annexin $\mathrm{V}$ and $1 \mu \mathrm{L} 100 \mu \mathrm{g} / \mathrm{mL}$ PI working solution were added to each

$4 \quad 100 \mu \mathrm{L}$ of cell suspension and then incubated at room temperature for $15 \mathrm{~min}$. After incubation,

$5400 \mu \mathrm{L}$ annexin-binding buffer was added and mixed gently, and the sample was chilled on

6 ice. Then, the stained cells were analyzed by flow cytometer.

$7 \quad$ 1.2.6. Casoase-3 like protein detection.

8 To determine the activation of caspase-like protein in bacteria, a fluorescently coupled high-

9 permeability caspase substrate inhibitor peptide reagent was experimentally coupled to a

10 fluorescence detection technology platform to provide a fast and stable interaction. The

11 experiments were conducted according to instructions provided by the CaspGLOW

12 Fluorescein Active Caspase-3 Staining Kit (Invitrogen). First, retrieved cells were added to a

13 tube at a concentration of approximately $1 \times 10^{6}$ cells $/ \mathrm{mL}$ in $300 \mu \mathrm{L}$ of complete medium.

14 Second, $1 \mu \mathrm{L}$ of FITC-DEVD-FMK was added into each tube and incubated for 45 min at 37

$15{ }^{\circ} \mathrm{C}$. Thirdly, the cells were centrifuged at $3000 \mathrm{rpm}$ for $5 \mathrm{~min}$ and supernatant removed. The

16 cells were then washed twice with $0.5 \mathrm{~mL}$ of wash buffer. Samples were placed on ice and then

17 analyzed by flow cytometer.

\subsubsection{Reactive Oxygen Species (ROS) Test.}

19 Oxidation-sensitive fluorescent probe 2,7-dichlorofluorescein diacetate (DCFH-DA, SigmaAldrich) was used to measure the level of intracellular ROS. DCFH-DA agent can diffuse through the cell membrane into the cell. Then it is deacetylated by the intracellular esterase to 
1 form nonfluorescent 2,7-dichlorofluorescein (DCFH). The DCFH reacts with ROS and

2 generate fluorescent 2,7-dichlorofluorescein (DCF). After adjusting the retrieved suspension

3 of $P$. aeruginosa to $1 \times 10^{6}$ cells $/ \mathrm{mL}$ and washing twice with $\mathrm{PBS}$, the sample was then

4 incubated with $20 \mu \mathrm{M}$ DCFH-DA in PBS for 30 min at $37^{\circ} \mathrm{C}$. Afterward, the bacterial cells

5 were washed twice to remove DCFH outside the cell. The suspension was put on ice. Then the

6 cell pellets were analyzed by flow cytometer. The experiment was performed under dark

7 conditions.

$8 \quad$ 1.2.8. Parameters of flow cytometer

9 We used a FACSCalibur flow cytometer (Becton Dickinson) to conduct flow cytometry experiments. The parameters are as follows:

11 Detecting ROS level: The FACSCalibur is was equipped with a 488-nm argon laser for excitation, and $530+/-15 \mathrm{~nm}$ (FL1) and $585+/-21 \mathrm{~nm}$ (FL2) emission filters, and used at a low flow rate. The following PMT voltage settings were: E01 (FSC), 520 (SSC), and 613 (FL1),659 (FL2).

Live/dead experiments: We also used FACSCalibur flow cytometer as describe above. The PMT voltage settings were: E01 (FSC), 458 (SSC), and 628 (FL1), 556 (FL3).

17 Outer membrane integrity: The PMT voltage settings were: E01 (FSC), 458 (SSC), and 600 (FL1), 458 (FL2). (FL3). 
2 (FL2).

3 Caspase-3 detection: The PMT voltage settings were: E01 (FSC), 505 (SSC), and 676 (FL1), $4772($ FL2).

$5 \quad$ No gate and compensation have been used in this work.

\section{1.3. Fluorescent microscopy}

7 The fluorescent micrographs were obtained by OLYPMUS IX 53. The suspended cells were

8 retrieved as described in the above sections. The staining processes were described under

9 methods for flow cytometry.

10 The CLSM images were taken by ZEISS LSM 800. Before imaging, bacteria were collected

11 and stained as described above, the stained suspension was dropped into a petri dish (MatTek)

12 then imaged. The images were taken within 3 min.

\subsection{Morphology investigation}

14 TEM micrographs were obtained by JEOL JEM-3010 electron microscope with an applied acceleration voltage of $300 \mathrm{kV}$. The pretreatment process was as follows: (1) The bacteria were drop cast on the surface of double-sided copper mesh and immersed for $10 \mathrm{~min}$ to ensure that

17 the bacteria were adsorbed onto the copper mesh. (2) A drop of sodium

18 dodecatungstophosphate hydrate was added on the copper mesh for 40 s. (3) After that, the copper mesh was removed and placed on filter paper for $10 \mathrm{~min}$. 
For TEM lamella, bacteria were retrieved from the surfaces and were fixed with $2.5 \%$

2 glutaraldehyde overnight. These bacteria were collected and embedded in epon 812 resin for

$390 \mathrm{~min}$. Samples were then placed at $60{ }^{\circ} \mathrm{C}$ for $48 \mathrm{~h}$ to allow resin polymerisation. Resin

4 embedded samples were sectioned on a Leica EM UC6 ultramicrotome. Then, the samples

5 were stained in $1 \%$ aqueous uranyl acetate $(1 \mathrm{~h})$ followed by lead aspartate $(200 \mu \mathrm{M})$ for 30

6 min. These were transferred to pioloform-coated TEM grids for microscopy

7 Ahead of SEM observation, the samples were pretreated with standard procedure as follows.

8 Bacteria were fixed with $2.5 \%$ paraformaldehyde and sequentially dehydrated for 10 min in

$9 \quad 10 \%, 30 \%, 50 \%, 70 \%, 80 \%, 90 \%, 95 \%$ and $100 \%(\times 2)(\mathrm{v} / \mathrm{v})$ ethanol. Tert butyl alcohol (TBA)

10 was used to replace ethanol. Then the samples underwent vacuum drying. The lower surface

11 tension of TBA effectively alleviates the cell deformation caused by capillary forces during drying. Samples were sputter-coated with Pt and imaged using a ZEISS Sigma 500 SEM at 10 $\mathrm{kV}$.

FIB milling of cells on the bSi surfaces was performed using an FEI Scios Dual-Beam system. The samples were fixed with $2.5 \%$ glutaraldehyde overnight and then washed three times with $0.1 \mathrm{M}$ cacodylate buffer containing $2 \mathrm{mM}$ calcium chloride. Then the OTO process was conducted, briefly, the samples were post fixed in $4 \%$ osmium tetraoxide and $3 \%$ potassium ferrocyanide for $60 \mathrm{~min}$ on ice. Following post fixation, samples were rinsed $(3 \times 5$ min) in $\mathrm{dH}_{2} \mathrm{O}$ before incubating with saturated thiocarbohydrazide solution for $20 \mathrm{~min}$. Additional $\mathrm{dH}_{2} \mathrm{O}$ washing steps $(3 \times 5 \mathrm{~min})$ were applied before incubation in $2 \%$ aqueous osmium for $30 \mathrm{~min}$ at room temperature. Following OTO processing, bacterial samples were 
1 stained in $1 \%$ aqueous uranyl acetate $\left(1 \mathrm{~h}\right.$ at $\left.4{ }^{\circ} \mathrm{C}\right)$ followed by lead aspartate $(200 \mu \mathrm{M})$ for 30

2 min in the dark. Between these steps, washing with $\mathrm{dH}_{2} \mathrm{O}$ was performed. After the final

3 washing step, bacterial samples were dehydrated and dried as previously described.

\section{1.5. Process of in-situ diluting for testing the influence of pipetting to the bacteria}

$52 \mathrm{~mL}$ of PBS was added in an empty well of a sterile 12 -well plate. Then the $\mathrm{bSi} / \mathrm{Si}$ slide with

6 attached bacteria was moved into this well slowly to minimize shear forces. $200 \mu \mathrm{L}$ of the

7 suspension was sampled and serially diluted for plate counting. The bSi slides were transferred

8 to ice cold PBS and imaged with a fluorescence microscope immediately. 

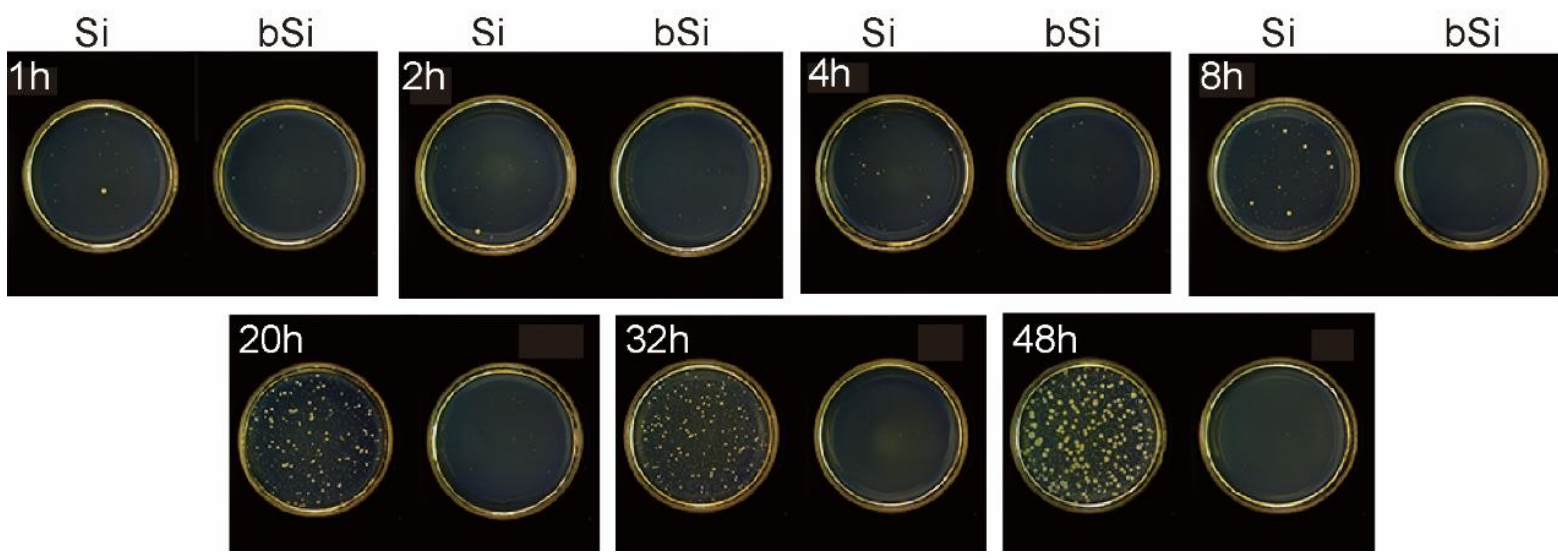

3 Figure S1. Plate count photographs after P. aeruginosa incubation on Si and bSi surfaces for

$4 \quad 1,2,4,8,20,32$, and $48 \mathrm{~h}$ in the cell density of $\mathrm{OD}_{600}=0.1$.

5 Table S1. Quantification of CFU following retrieval from the bSi and Si surfaces after $6 \mathrm{~h}$

6 incubation in the cell density of $\mathrm{OD}_{600}=5$.

Silicon wafer

Colony count
283

284

308
Black silicon

103

89

97 

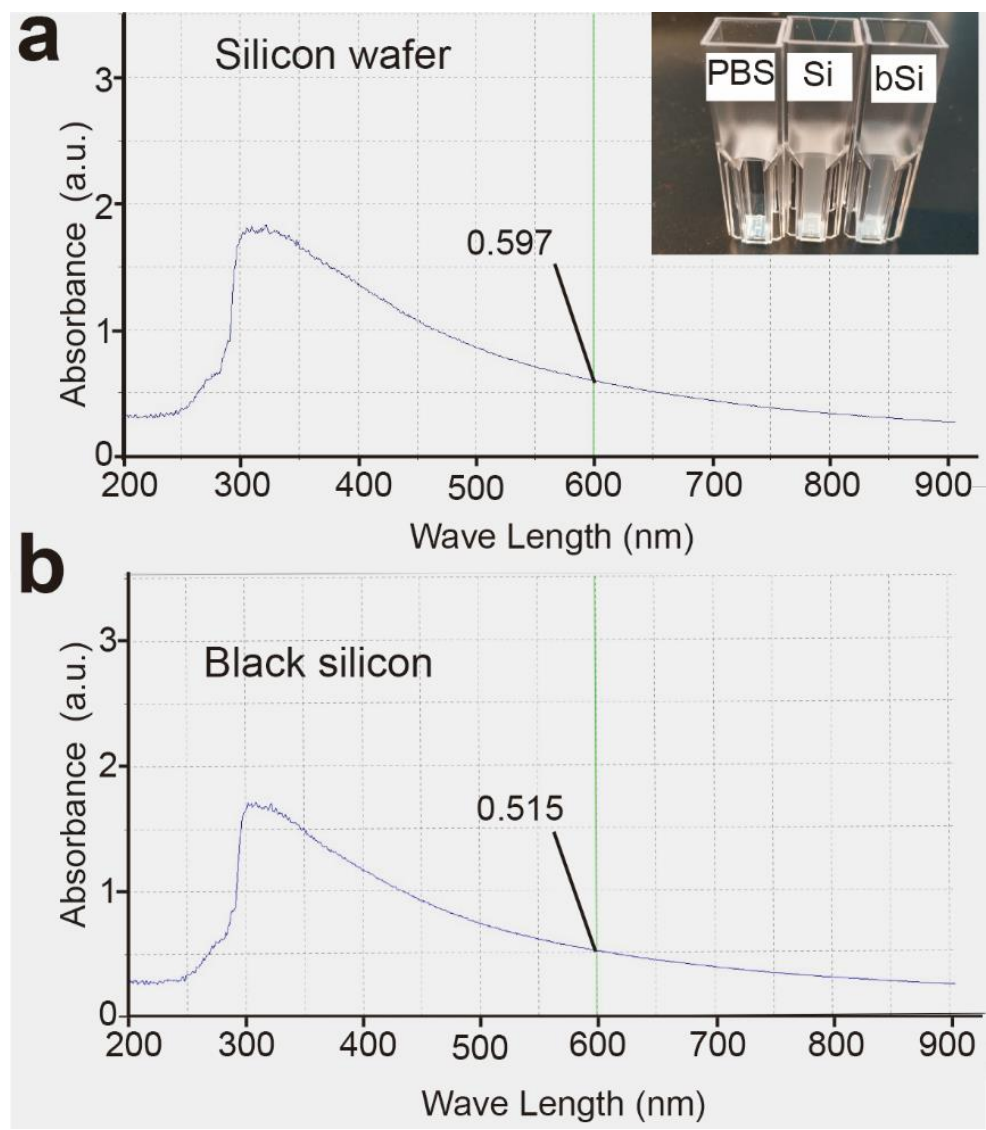

2 Figure S2. Cell density on the Si wafer and bSi after diluting $10 \times$ by PBS in the cell density 3 of $\mathrm{OD}_{600}=5$.

4 The proportion of live cells ( $20 \mu \mathrm{L}$ of an initial seeding density of $2 \times 10^{7}$ cells) on the bSi

5 surfaces was determined by plate counting techniques. After $6 \mathrm{~h}$, the bacterial cells were

6 retrieved from the surfaces by gentle pipetting, as described in the main text, then the cell

7 density was obtained. The cell density $\left(\mathrm{OD}_{600}\right)$ of the suspensions on $\mathrm{bSi}$ and $\mathrm{Si}$ wafers diluted

$8 \quad 10$-fold were 0.515 and 0.597 , respectively (Figure S2). This was to calibrate the total amount

9 of cells on the black silicon (both dead and live cells), which cannot be achieved from colony

10 counting techniques. In order to compare the bactericidal efficiency tested by both flow

11 cytometry and plate counting techniques, here we can calculate the percentage of non-viable 
1 cells (which is different to bactericidal efficiency) to indicate the percentage of dead cells on

2 each surface by:

$3 \quad$ Percentage of non-viable cells $=\frac{\text { Amount of dead cells }}{\text { Amount of total cells }}$

4 Percentage of non-viable cells bSi $\left(\mathrm{PNC}_{\mathrm{b}}\right)$ and percentage of non-viable cells of silicon wafer

$5 \quad\left(\mathrm{PNC}_{\mathrm{s}}\right)$ meet the following equation:

6 live cells on $\mathrm{bSi}=(1-$ bactericidal efficiency $) \times$ live cells on $\mathrm{Si}$

$7 \quad C D_{b} \cdot\left(1-P N C_{b}\right)=\left(1-B E_{b}\right) \cdot C D_{s} \cdot\left(1-P N C_{s}\right)$

8 where $B E_{b}$ is bactericidal efficiency of $\mathrm{bSi}, C D_{b}$ is cell density of bSi and $C D_{s}$ is cell density

9 of the silicon wafer. Because $P N C_{s}$ was negligible $\left(P N C_{s}=0\right), P N C_{b}$ of $61.65 \%$ was obtained by Equation (2), indicating a $61.65 \%$ killing efficiency as obtained from plate count methods. 


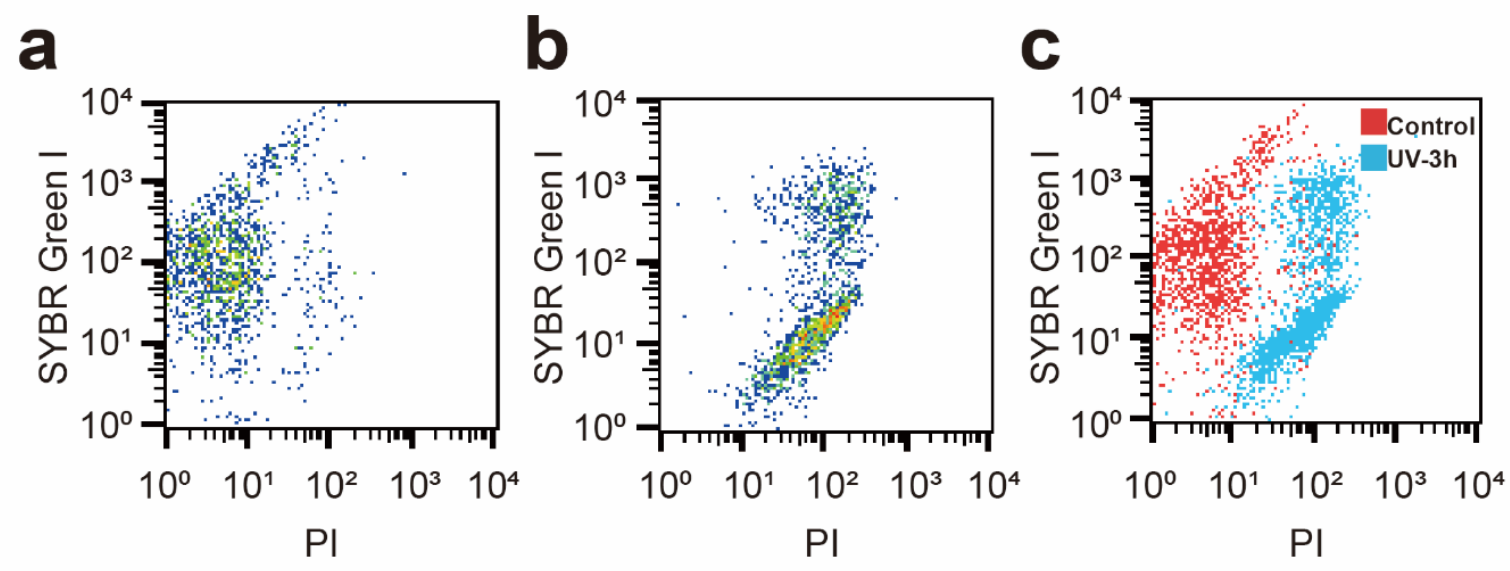

1

2 Figure S3. Flow cytometer plots of live/dead labeling of $P$. aeruginosa control and positive

3 control cells. The flow cytometer plots of control (a) which is incubated in PBS in $20{ }^{\circ} \mathrm{C}$ for 3

$4 \mathrm{~h}$, positive control (b) which is UV-radiated for $3 \mathrm{~h}$. (c) is the merging of (a) and (b) to show

5 the positional relationship of clusters of dead and live cells. 

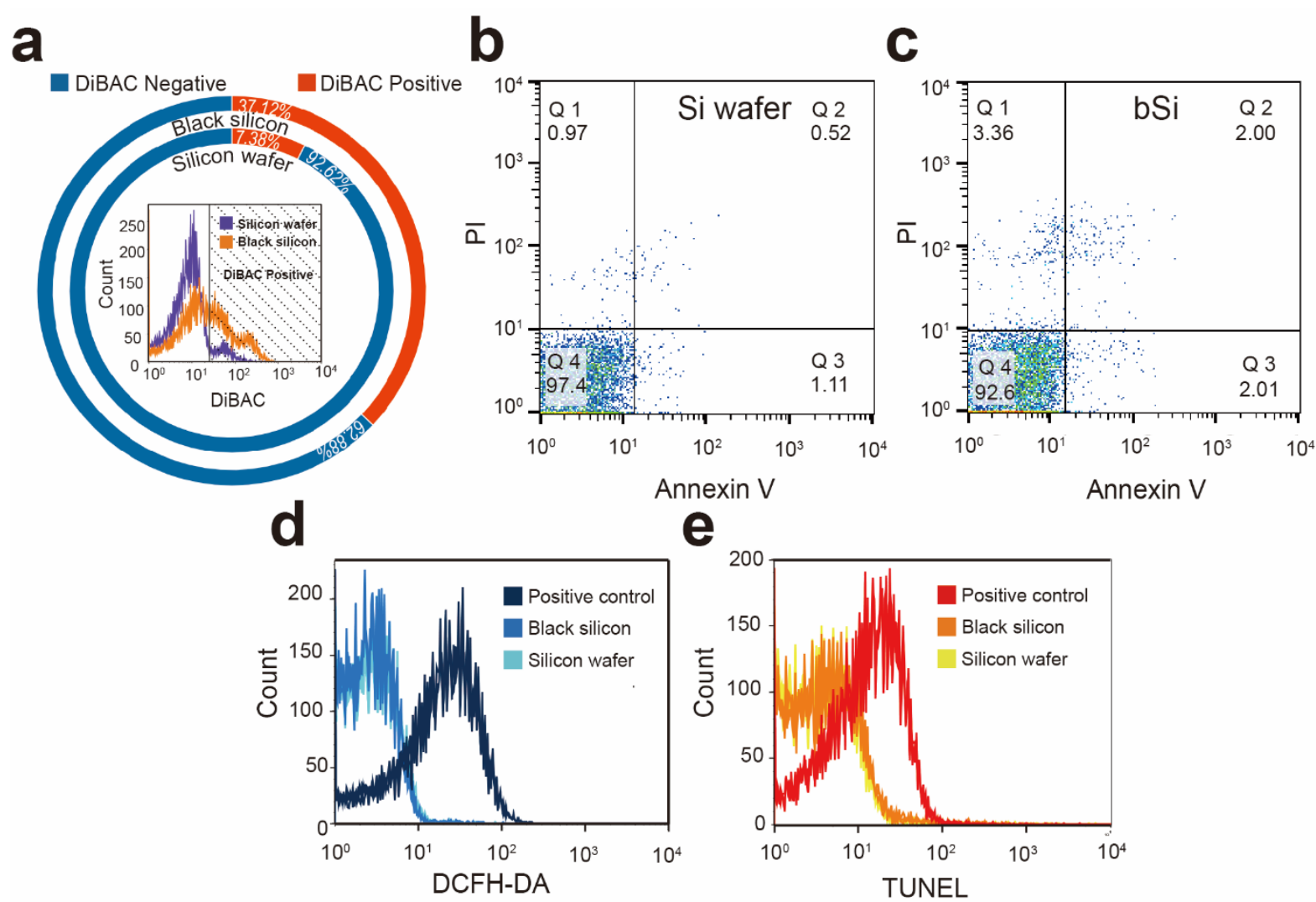

e

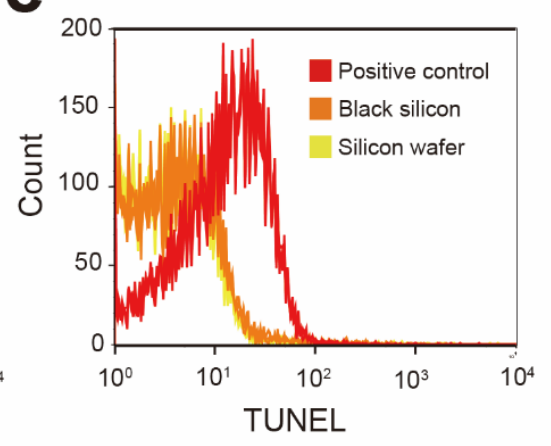

2 Figure S4. Flow cytometric analysis following P. aeruginosa incubation on bSi and Si surfaces

3 for 6 h. (a) Flow cytometry histogram and the increased proportion of DiBAC4(3) positive

4 events indicate the compromised outer membrane of $P$. aeruginosa bacteria on the bSi after 6

5 h incubation. (b, c) Phosphatidylserine exposure analysis conducted by flow cytometer after

6 incubation on bSi and Si surfaces for $6 \mathrm{~h}$. There were few PI positive and annexin $\mathrm{V}$ positive

7 cells on both the Si wafer (b) and the bSi (c). (d) Fluorescence histogram of intracellular ROS

8 level showing bacteria treated by bSi or $1 \%$ of $\mathrm{H}_{2} \mathrm{O}_{2}$ (positive control) for $6 \mathrm{~h}$. (e)

9 Representative flow cytometer fluorescence histograms of TUNEL assay of bacteria treated by

$10 \mathrm{bSi}$ or UV radiation (positive control) for $6 \mathrm{~h}$. The TUNEL assay was used to label the large

11 number of exposed 3'-hydroxyl ends due to DNA breaks. 
2 a voltage-sensitive dye which differs in its ability to diffuse across depolarized membranes,

3 and to be activated by binding to lipid molecules intracellularly. It is commonly used in

4 eukaryotic models to assay for alterations in charge across the mitochondrial membrane. In

5 bacterial models, however, it is used for characterizing the decreased bacterial membrane

6 potential $(\Delta \Psi)$ at the bacterial outer membrane. If the outer membrane is compromised, the $\Delta \Psi$

7 at the bacterial outer membrane would be decreased and the $\operatorname{DiBAC}_{4}(3)$ positive events would

8 be increased. The $\operatorname{DiBAC}_{4}(3)$ positive events, of the total 10,000 events, increased from $7.38 \%$

9 to $37.12 \%$ following $P$. aeruginosa incubation on bSi surfaces for $6 \mathrm{~h}$ (Figure S4a).

10 Considering that a proportion of the total events recorded were attributed to bacterial debris

11 which were $\operatorname{DiBAC}_{4}(3)$ negative, the real portion of $\operatorname{DiBAC}_{4}(3)$ positive cells should be more

12 than $37.12 \%$. The results indicated that more than $37.12 \%$ of the bacteria on the bSi possessed

13 a compromised outer membrane. 


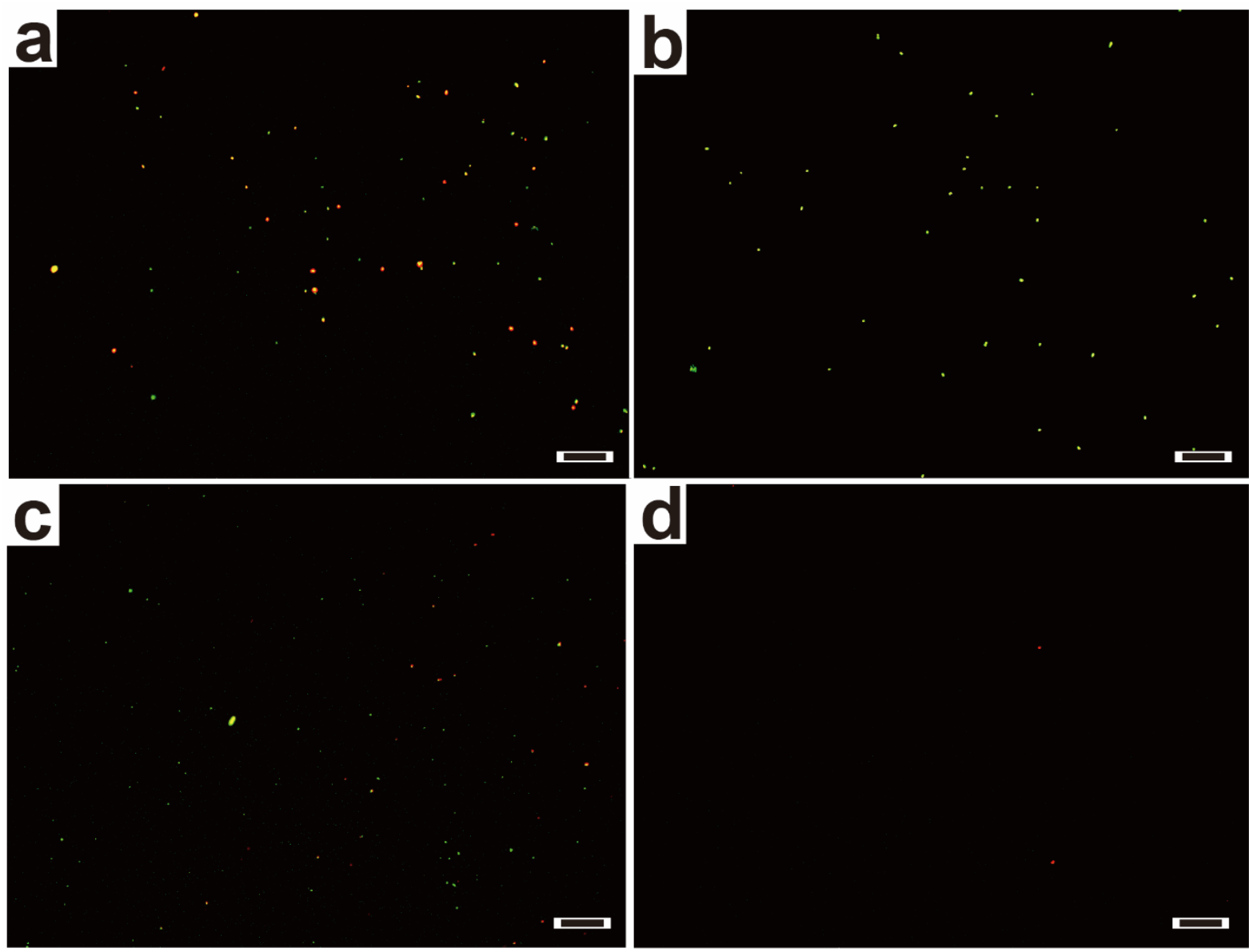

2 Figure S5. Fluorescence micrographs of irreversibly adherent $P$. aeruginosa cells on the bSi

3 (a, c) and Si wafer (b, d) after 6 h. Fluorescent dyes SYBR Green I and PI were used in $(\mathrm{a}, \mathrm{b})$,

4 annexin V and PI were used in (c, d). Scale bars in (a-d) are $50 \mu \mathrm{m}$. 

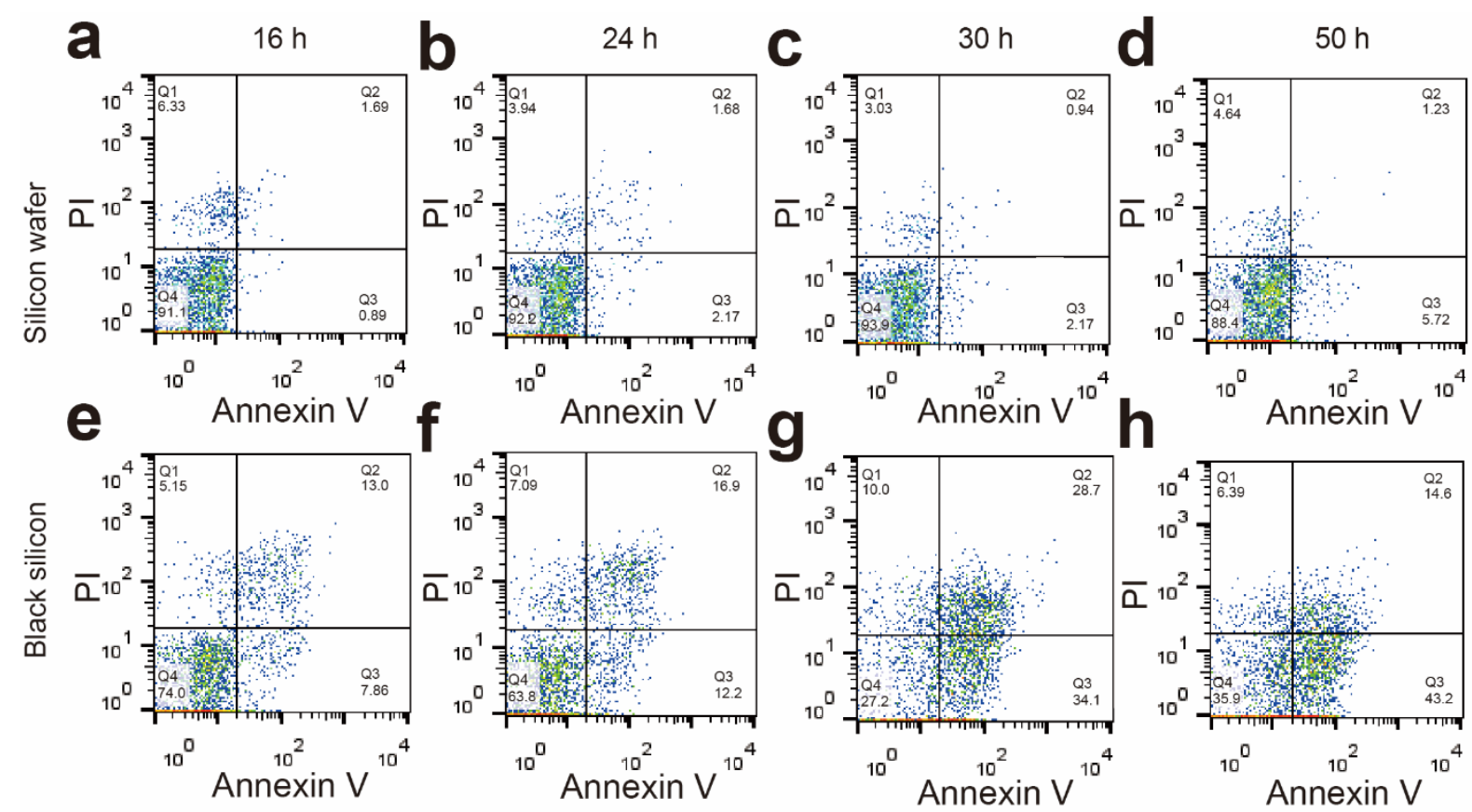

2 Figure S6. Phosphatidylserine exposure analysis of non-adherent cells conducted by flow cytometer after incubation on bSi and Si surfaces for $16 \mathrm{~h}, 24 \mathrm{~h}, 30 \mathrm{~h}$, and $50 \mathrm{~h}$. There are few PI positive and annexin $\mathrm{V}$ positive cells on the $\mathrm{Si}$ wafer (a-d). There are many annexin V positive cells on the bSi wafer (e-h). Percentage of events in each quarter are marked at the corresponding position.

After bacteria were incubated on bSi and Si wafer for $16 \mathrm{~h}, 24 \mathrm{~h}, 30 \mathrm{~h}$ and $50 \mathrm{~h}$ respectively,

8 the cells were retrieved to be analyzed by flow cytometry. From $16 \mathrm{~h}$ to $50 \mathrm{~h}$, for the cells

9 retrieved from Si wafer, the percentage of PI positive cells were low and comparable, the

10 percentage of annexin $\mathrm{V}$ positive cells were negligible (less than $7 \%$ in one case and less than

$114 \%$ in the others, Figure S7a-d). As for cells retrieved from bSi surface, the percentage of annexin V positive cells were increased from $2.47 \%(6 \mathrm{~h})$ to $62.8 \%(30 \mathrm{~h})$ (Figure S4, Figure

S7e-g). The percentage of PI positive cells followed the same trend (Figure S7e-h). 


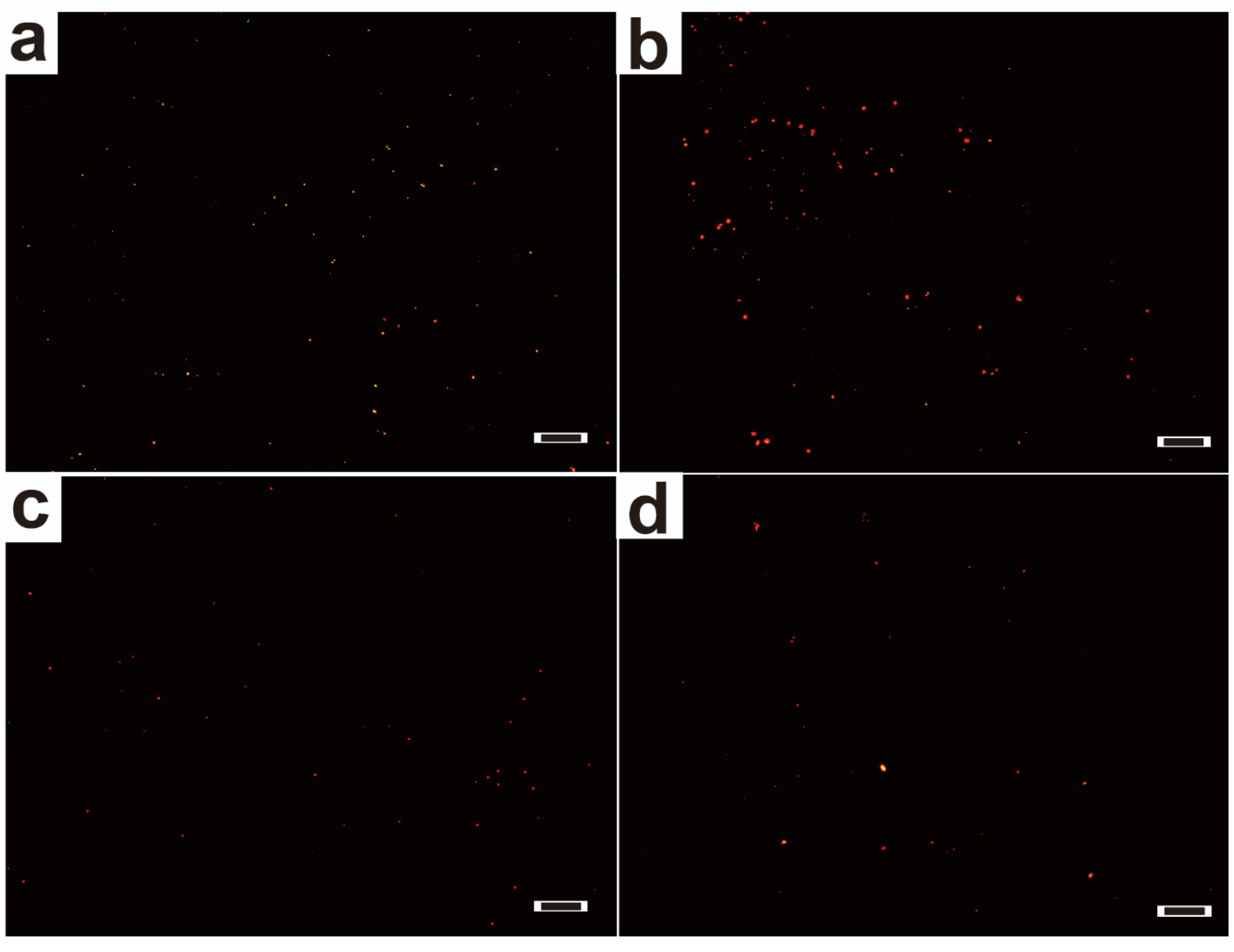

2 Figure S7. Fluorescence micrographs of Annexin V/ PI uptake in P. aeruginosa cells adhered

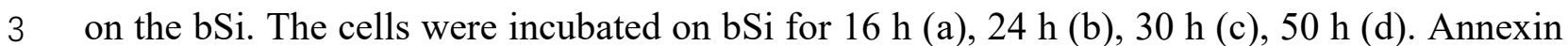

4 V/PI kit is used to label the PS exposure and the dead cells, respectively. Scale bars are $50 \mu \mathrm{m}$. 


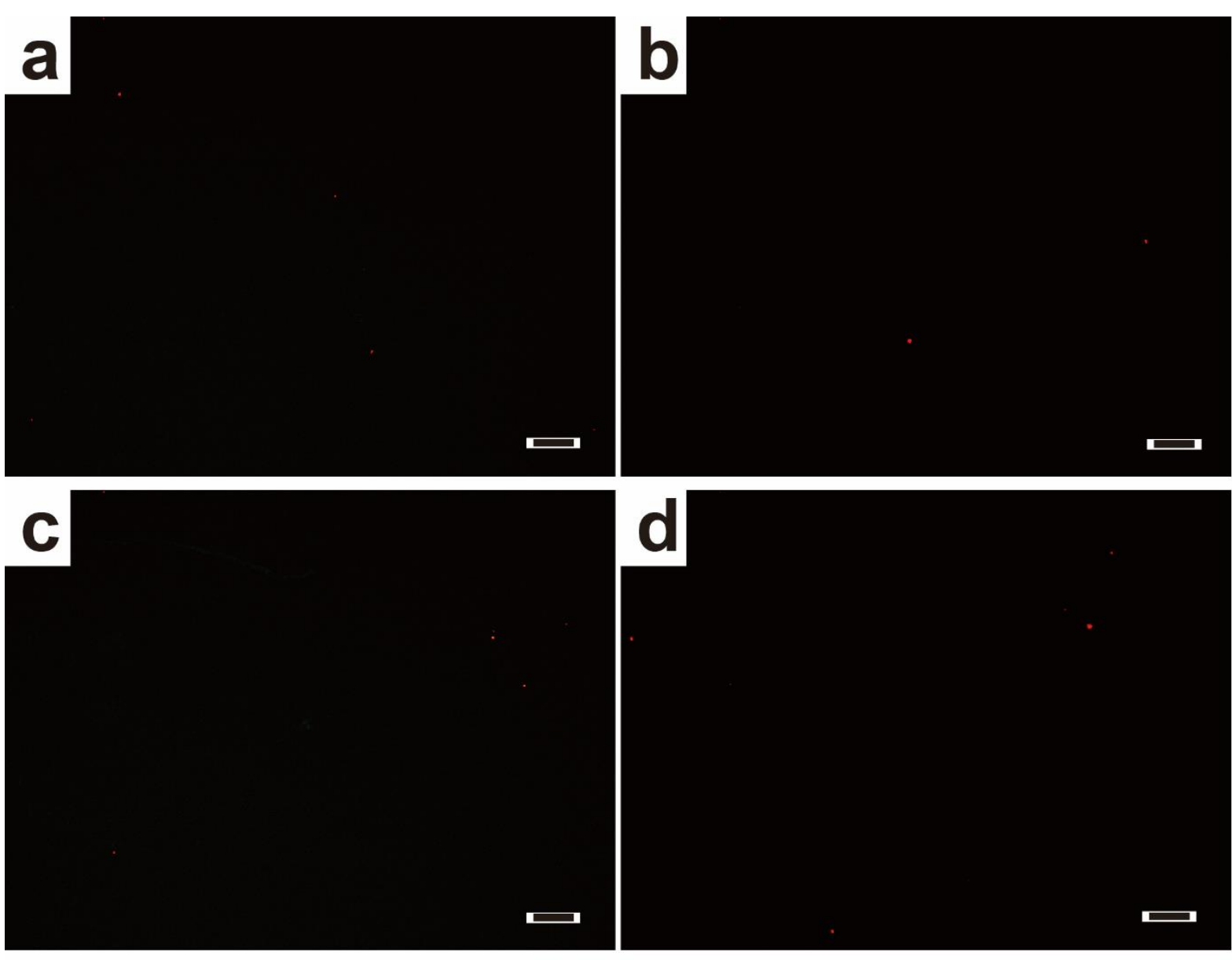

2 Figure S8. Fluorescence microscopy micrographs of Annexin V/ PI uptake in P. aeruginosa 3 cells adhered on the Si wafer. The cells were incubated on Si wafer for $16 \mathrm{~h}(\mathrm{a}), 24 \mathrm{~h}(\mathrm{~b}), 30 \mathrm{~h}$ 4 (c), $50 \mathrm{~h}(\mathrm{~d})$. Annexin V/PI kit is used to label the PS exposure and the dead cells, respectively.

$5 \quad$ Scale bars are $50 \mu \mathrm{m}$.

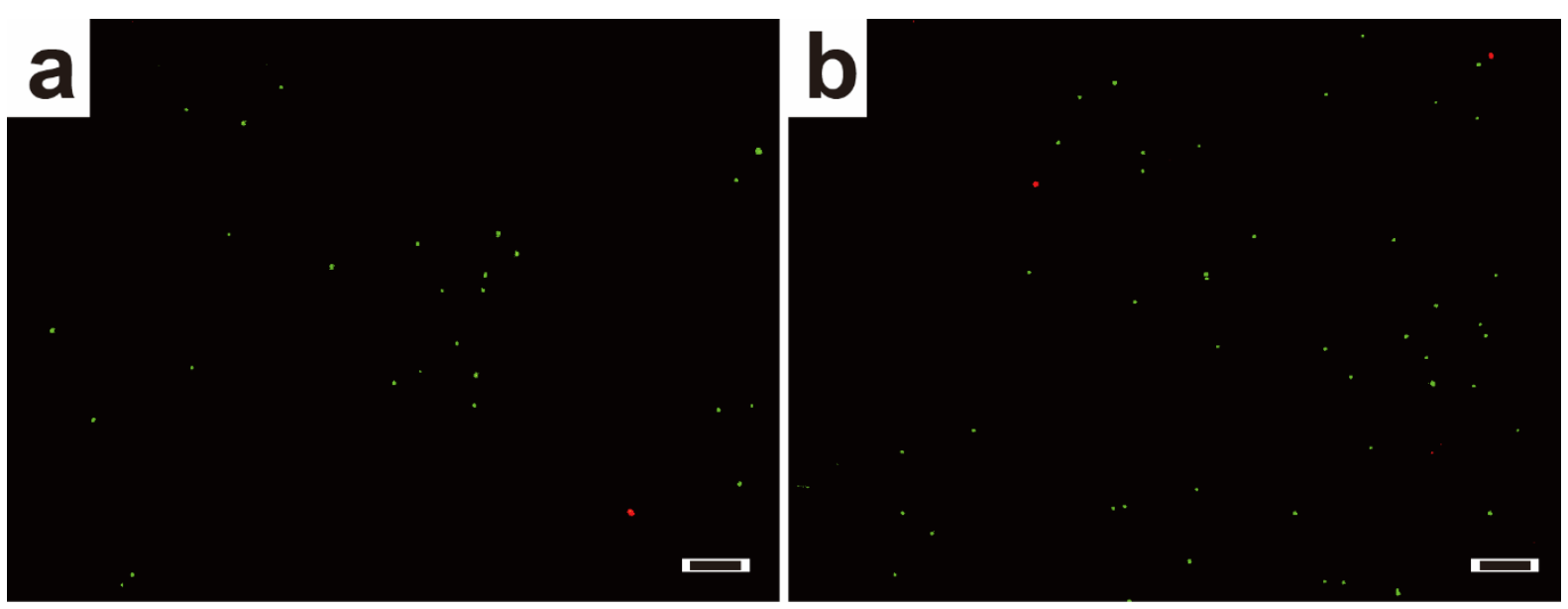


1 Figure S9. Amount of the bacterial cells adhered on the surface of Si wafer after incubating for

$26 \mathrm{~h}(\mathrm{a})$ and $50 \mathrm{~h}(\mathrm{~b})$. Fluorescent probes SYBR Green I and PI were used. The absence of 3 annexin $\mathrm{V}+$ and $\mathrm{PI}+$ signal in Figure $\mathrm{S} 8$ was not because of the absence of cells on the surface.

4 Scale bars are $50 \mu \mathrm{m}$.

5 


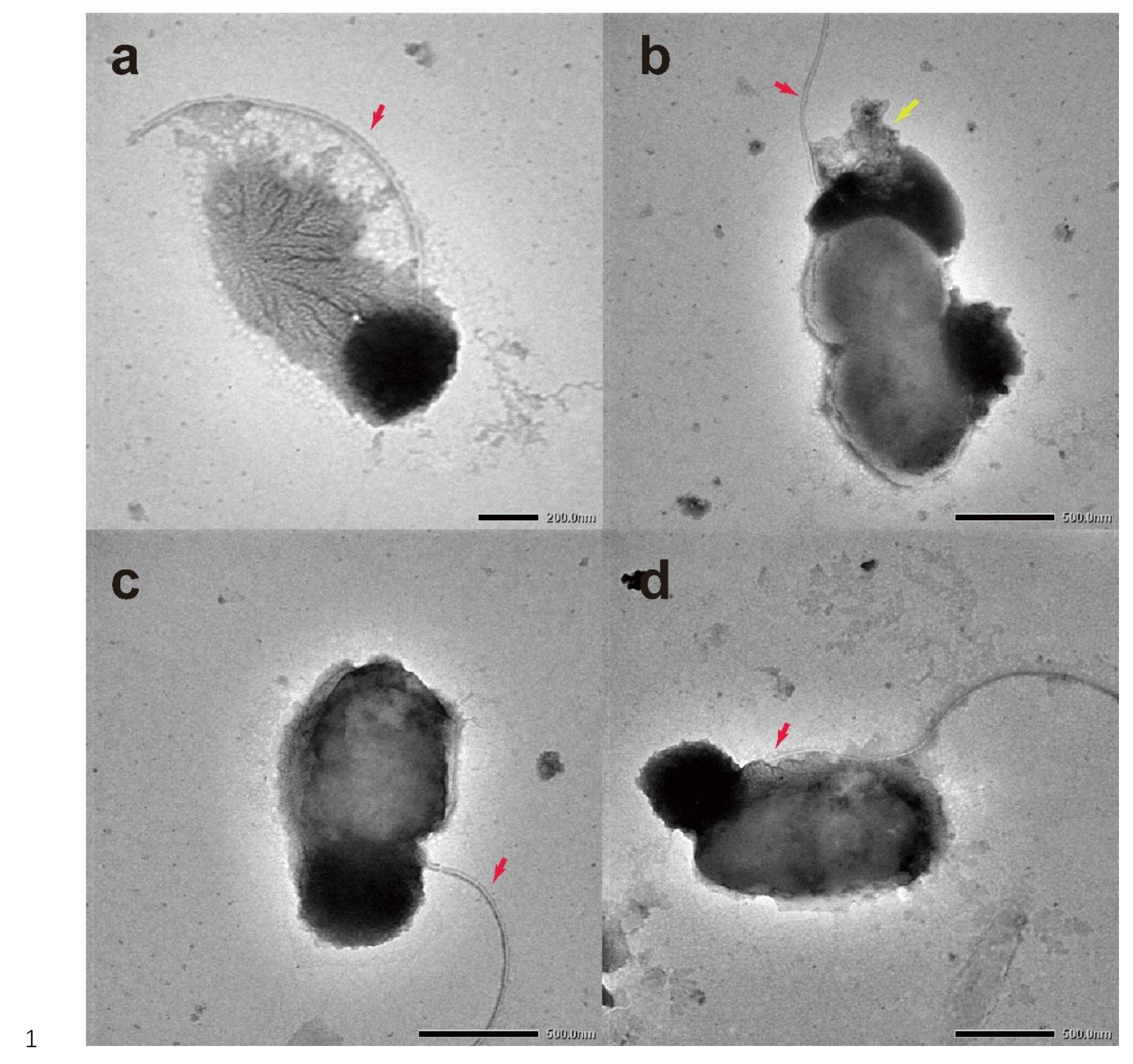

2 Figure S10. TEM micrographs of $P$. aeruginosa cells in the suspension, which were retrieved

3 from bSi surfaces. Cytoplasmic substances are observed in the spherical object in (b), as

$4 \quad$ indicated by the yellow arrow. The flagella are indicated by the red arrows. 

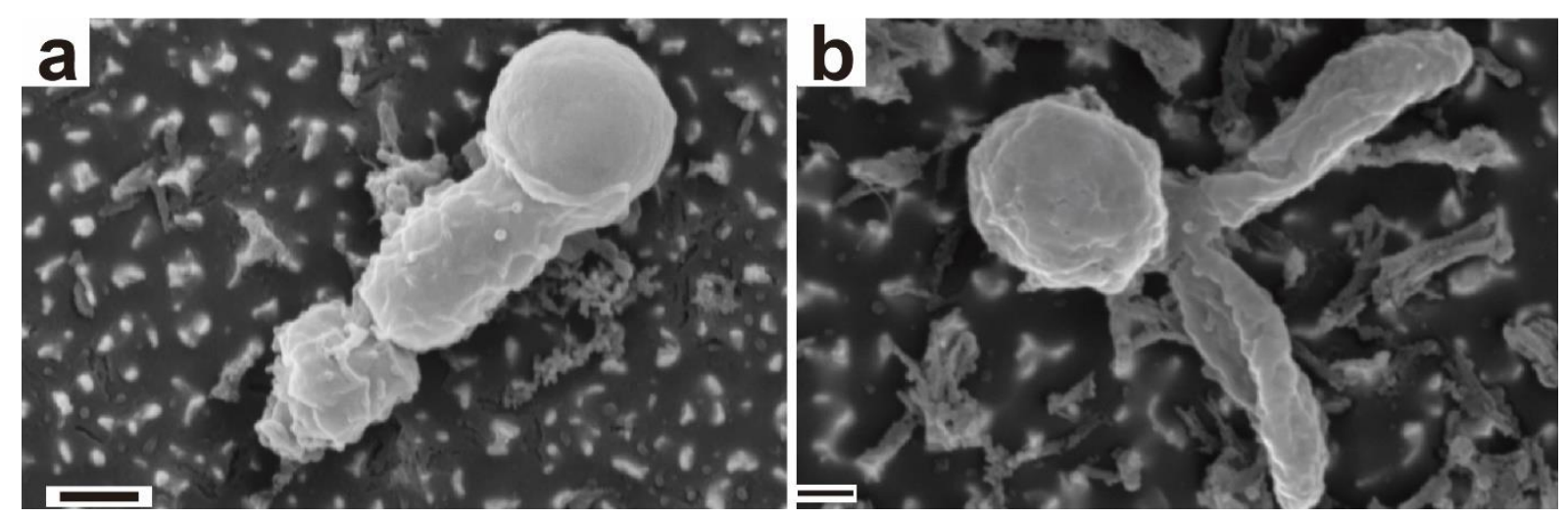

2 Figure S11. Representative SEM micrographs showing the cell morphology of $P$. aeruginosa

3 on bSi surfaces. The scale bars are $200 \mathrm{~nm}$.

4 

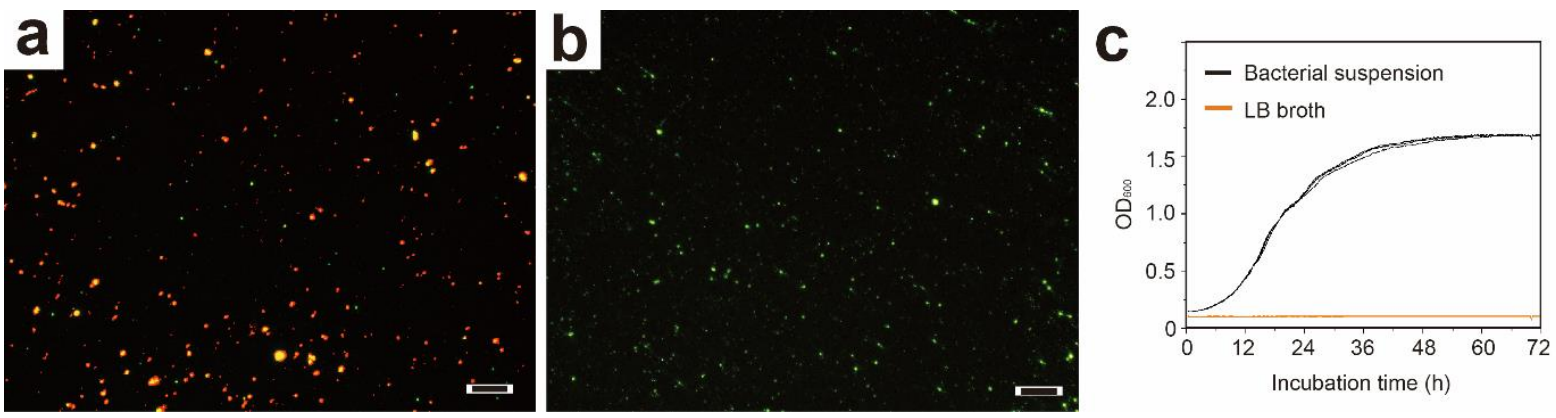

2 Figure S12. Fluorescence micrographs of bSi (a) and Si wafer (b) after $72 \mathrm{~h}$ incubation, and

3 the bacteria growth curve in the same incubation condition (c). SYBR Green I and PI were

4 used to distinguish between the total (green) and dead (red) bacteria on the sample. The scale

5 bars are $50 \mu \mathrm{m}$. We chose the area with the densest cells and acquired the micrographs above.

6 There were negligible adherent cells on the surface even after $72 \mathrm{~h}$ incubation: less than 300

7 cells per image, equating to less than $3 \times 10^{5}$ cells per slide. The cell density on the slides is

8 approximately $\mathrm{OD}_{600}=1.7\left(3.4 \times 10^{8} \mathrm{CFU} / \mathrm{mL}\right)^{6}$ at the end of $72 \mathrm{~h}$ incubation (c). There were approximately $6.8 \times 10^{6}$ cells in the $20 \mu \mathrm{L}$ inoculating suspension. Thus, the adherent cells were less than $5 \%$ of total bacteria.

11 The majority of bacterial cells were able to be retrieved and negligible cells remained on the surfaces of bSi and Si wafer, the number of cells adhered on these two kinds of surfaces were comparable and negligible. 


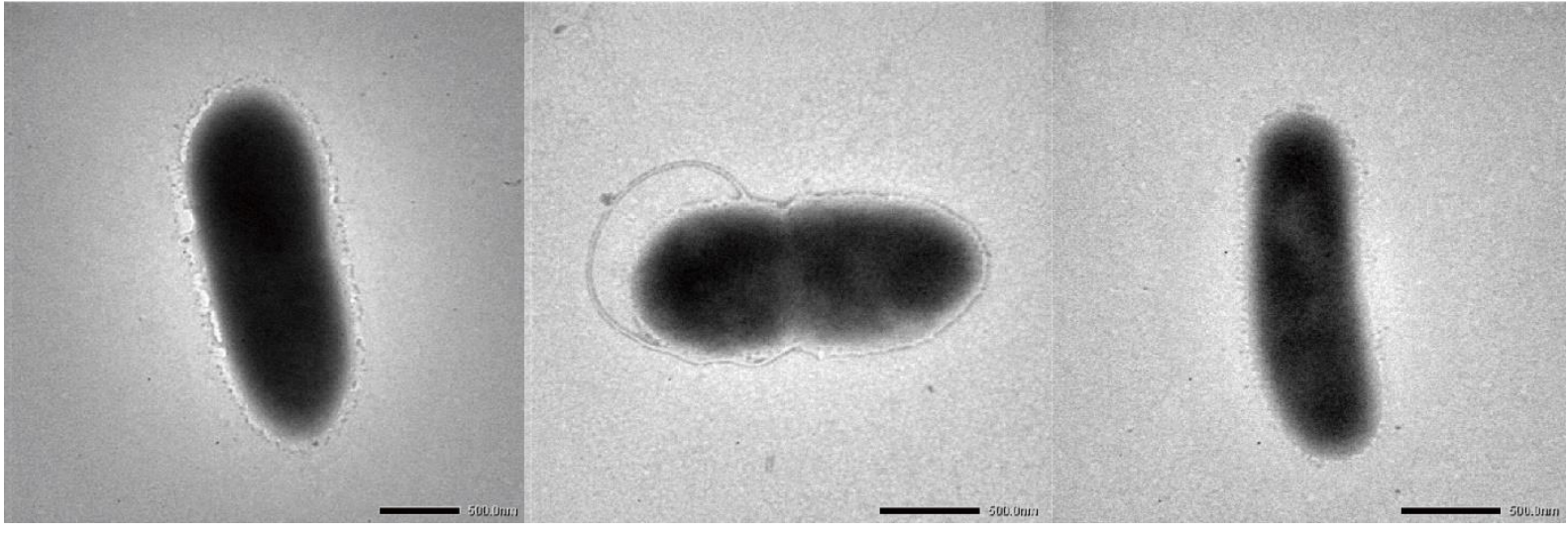

2 Figure S13. TEM micrographs of $P$. aeruginosa cells retrieved from planar Si surfaces, used

3 as the control substratum. Scale bars are $500 \mathrm{~nm}$. 

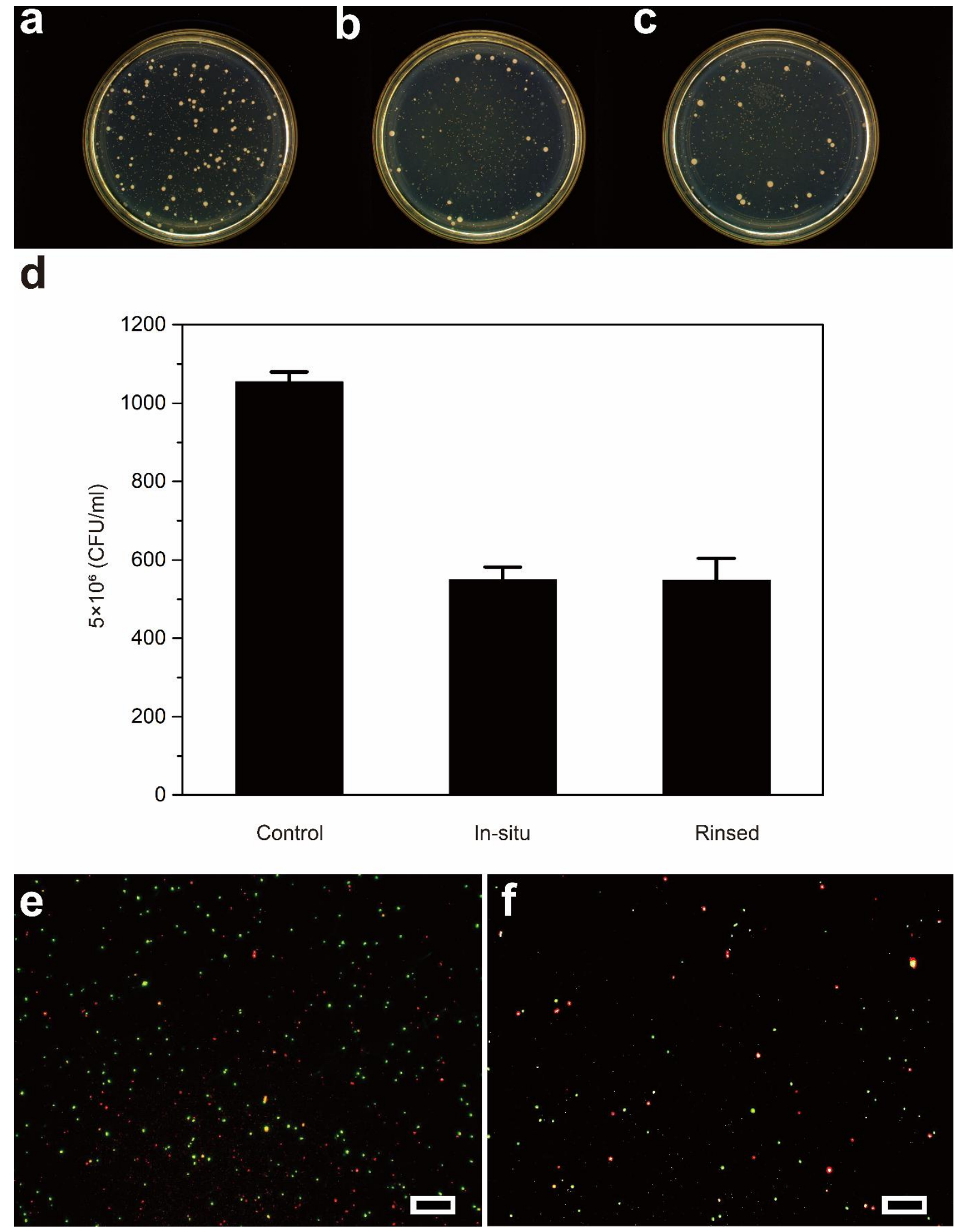

2 Figure S14. Plate count photographs after $6 \mathrm{~h}$ of $P$. aeruginosa incubation on Si/control (a) and

3 bSi surfaces (b, c). Samples in (b) were diluted in-situ, whereas samples in (c) were rinsed from

4 the surface of bSi and diluted for plate count $\left(5 \times 10^{6}\right.$ times $)$. Quantification of CFU/mL is 
1 shown in (d). The rinsing process did not affect the viability of the retrieved bacterial cells.

2 Fluorescence micrographs of adherent cells after rinsing (f) and in-situ dilution (e). SYBR

3 Green I and PI were used to distinguish between the total (green) and dead (red) bacteria on

4 the sample. Scale bars are $50 \mu \mathrm{m}$. The live/dead ratio was comparable in (e) and (f), despite

5 more cells being left in the in-situ dilution set, confirming that the rinsing process was helpful

6 to retrieve almost all of the cell but did not affect the viability of the bacterial cells significantly. 

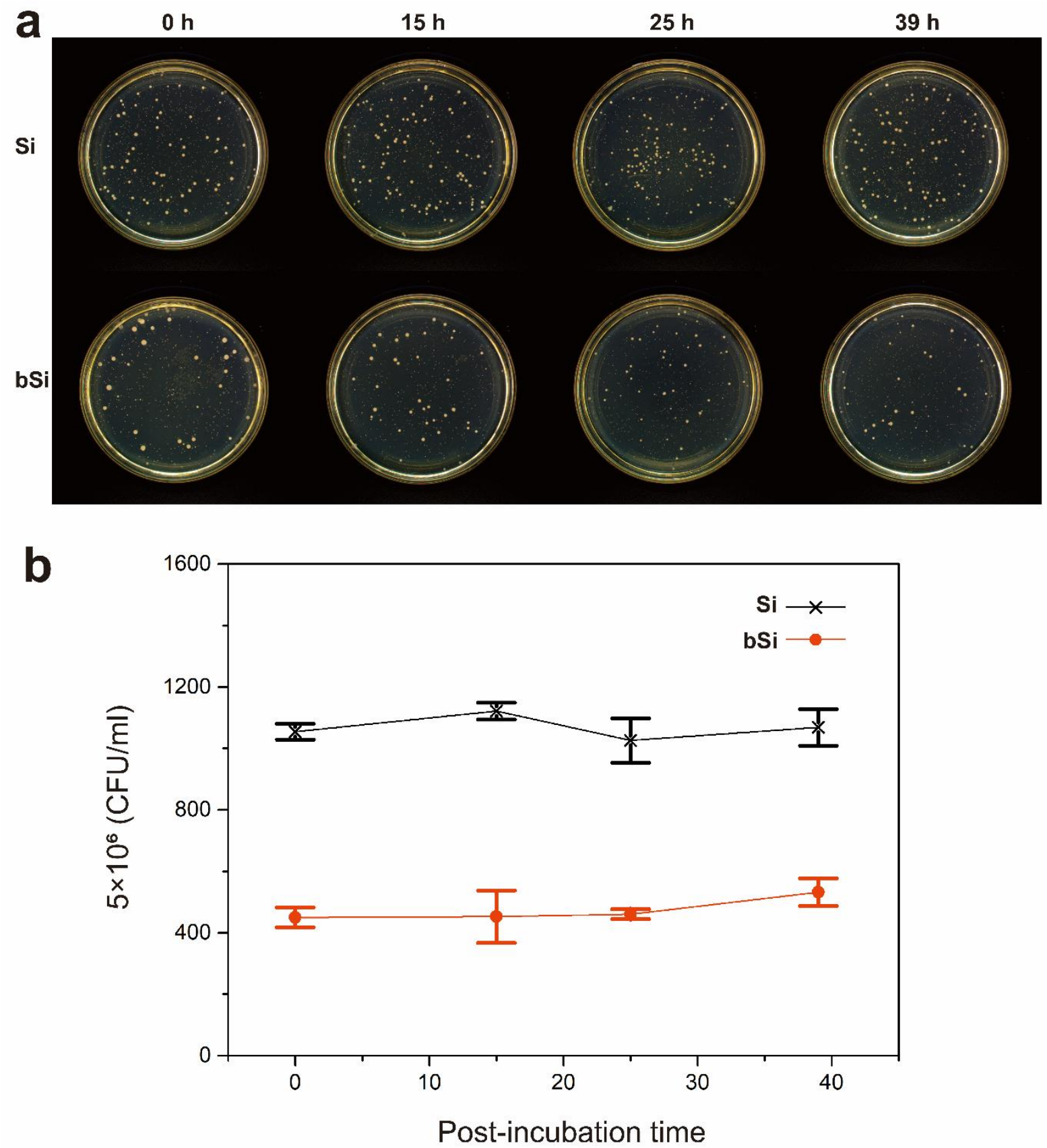

2 Figure S15. Plate count photos after corresponding time of post-stressed incubation in PBS (a).

3 The samples were retrieved from the surfaces of $\mathrm{Si} / \mathrm{bSi}$ after $6 \mathrm{~h}$ incubation and then incubated

4 in PBS. Quantification of CFU/mL (b). PBS alone did not significantly affect the viability of

5 P. aeruginosa; however, the injured bacteria cannot be resuscitated in physiological buffer. 

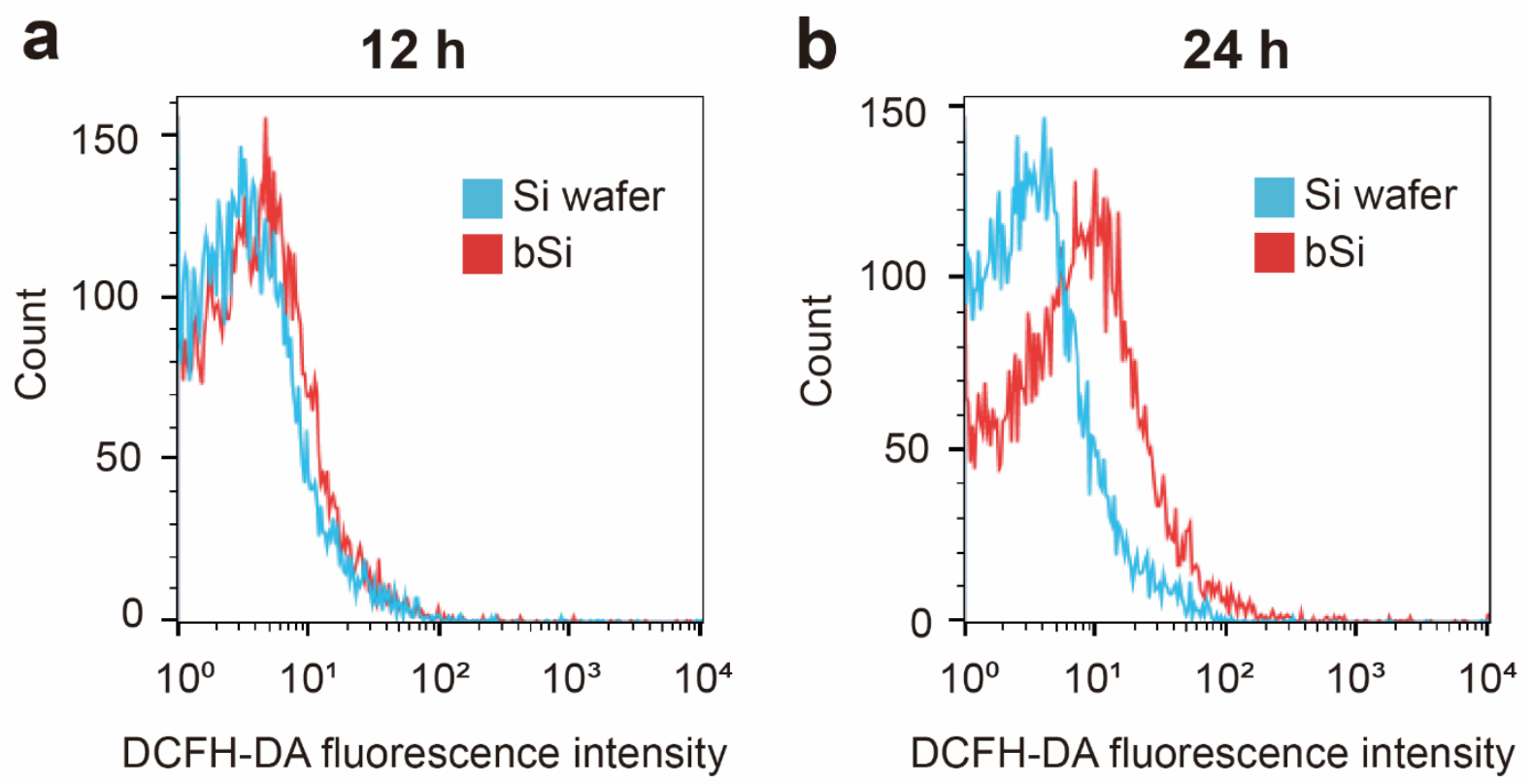

2 Figure S16. The representative fluorescence intensity histograms for ROS after $12 \mathrm{~h}$ (a) and 24

$3 \mathrm{~h}(\mathrm{~b})$ incubation on the bSi and control surface. The increase of ROS level after $12 \mathrm{~h}$ incubation

4 on bSi was not significant according to the fluorescence data. The ROS level of cells on bSi

5 was significantly increased after $24 \mathrm{~h}$.

6 


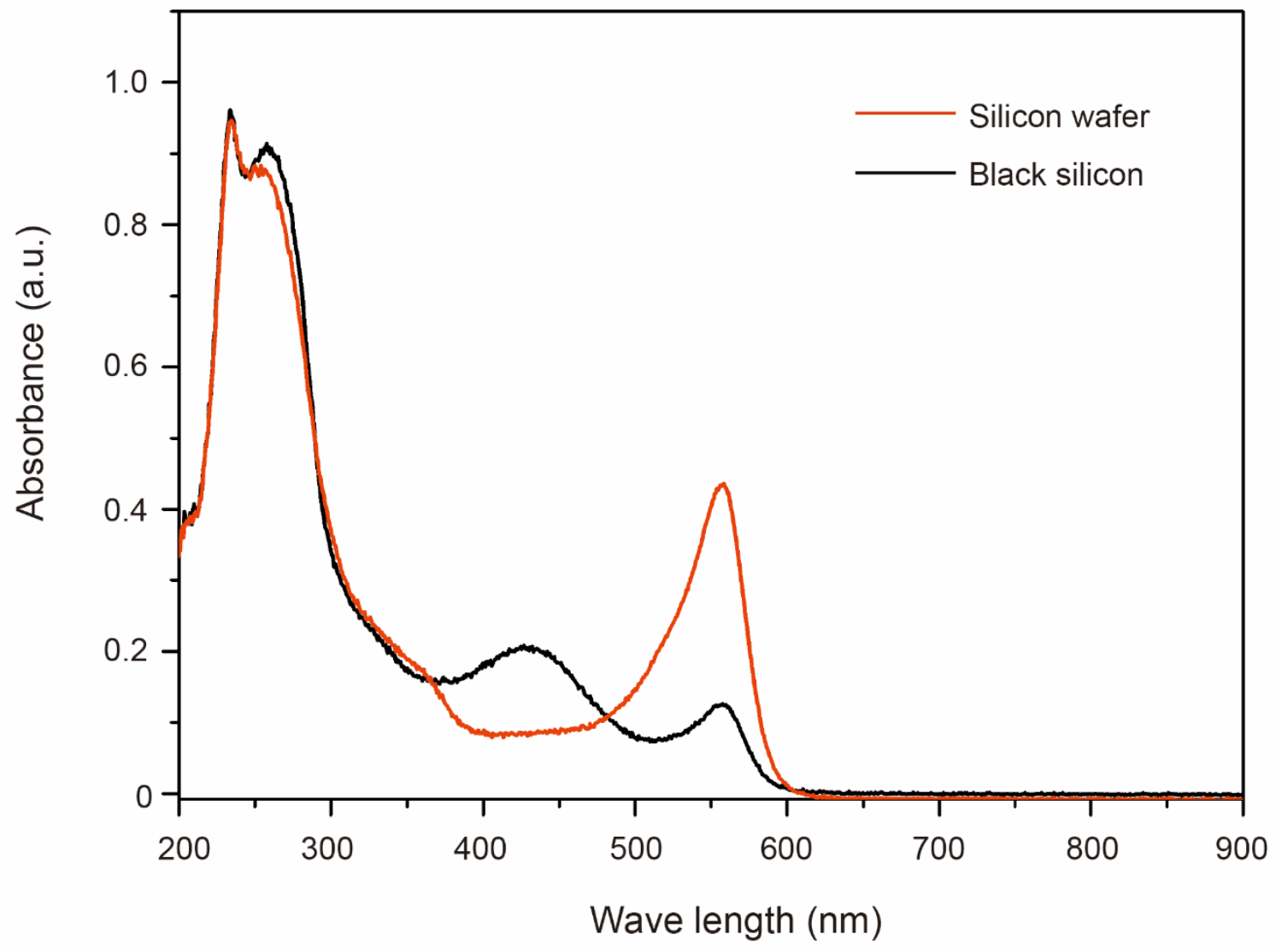

1

2 Figure S17. The UV-Vis absorption spectrum of the $10 \times$ diluted (by DI water) medium (LB

3 broth) with $0.0002 \%$ phenol red indicator. The medium was centrifuged from the suspension

$4 \quad\left(20 \mu \mathrm{l}\right.$ in the bacteria cell density of $\left.\mathrm{OD}_{600}=0.1\right)$ which was incubated on the surfaces $(\mathrm{bSi}$ and

5 Si wafer) for $24 \mathrm{~h}$ in $20{ }^{\circ} \mathrm{C}$ then retrieved (dropping $200 \mu \mathrm{l}$ of DI water on the surface and

6 collect the suspension). The color of phenol red indicator changes with $\mathrm{pH}$ of the solution. The

7 UV-Vis absorption spectrum of the solution from bSi exhibited a band between $400 \mathrm{~nm}-500$

$8 \mathrm{~nm}$, indicating the absorbance of bule light. In this case, contrasting with the pink color (phenol

9 red indicator) of the control, the medium from bSi turn the phenol red indicator into orange, it

10 indicated a lower $\mathrm{pH}$ of the suspension on the bSi after incubating for $24 \mathrm{~h}$. We inferred that it 
1 may be a result of changes in bacterial metabolism incurred by mechano-bactericidal actions.

2 However, it requires further investigations in the future. 

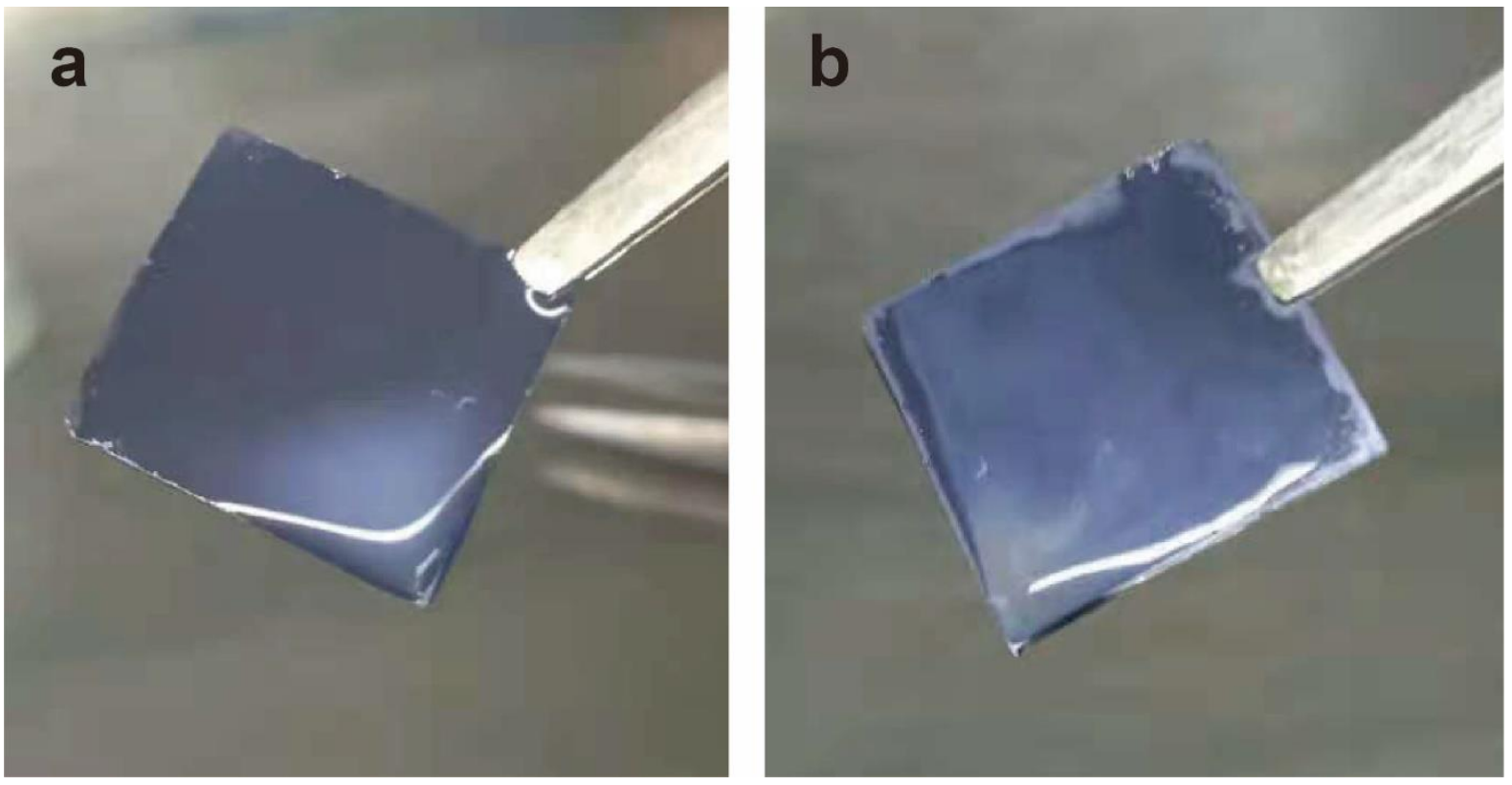

2 Figure S18. Photos of bSi with $20 \mu$ bacterial suspension (LB broth, $\mathrm{OD}_{600}=5$ ) on their

3 surfaces. The surface was fully wetted by the fluid before the incubation (a), and it was not dry

4 out after incubating for $50 \mathrm{~h}(\mathrm{~b})$ in $20^{\circ} \mathrm{C}$. 


\section{REFERENCES}

[1] Michalska, M.; Gambacorta, F.; Divan, R.; Aranson, I. S.; Sokolov, A.;

Noirot, P.; Laible, P. D., Tuning antimicrobial properties of biomimetic nanopatterned surfaces. Nanoscale 2018, 10 (14), 6639-6650.

[2] Jansen, H.; Deboer, M.; Legtenberg, R.; Elwenspoek, M., The Black Silicon Method - A Universal Method For Determining The Parameter Setting of A Fluorine-Based Reactive Ion Etcher In Deep Silicon Trench Etching With Profile Control. Journal of Micromechanics and Microengineering 1995, 5 (2), 115-120.

[3] Kim, D. J.; Chung, S. G.; Lee, S. H.; Choi, J. W., Relation of microbial biomass to counting units for Pseudomonas aeruginosa. Afr. J. Microbiol. Res. 2012, 6 (21), 4620-4622.

1 [4] Ivanova, E. P.; Hasan, J.; Webb, H. K.; Gervinskas, G.; Juodkazis, S.; Vi Khanh, T.; Wu, A. H. F.; Lamb, R. N.; Baulin, V. A.; Watson, G. S.; Watson, J. A.; Mainwaring, D. E.; Crawford, R. J., Bactericidal activity of black silicon. Nature Communications 2013, 4, 2838.

[5] Droumpali, A.; Hubner, J.; Gram, L.; Taboryski, R., Fabrication of Microstructured Surface Topologies for the Promotion of Marine Bacteria Biofilm. Micromachines (Basel) 2021, 12 (8), 926.

[6] Berney, M.; Hammes, F.; Bosshard, F.; Weilenmann, H.-U.; Egli, T., Assessment and interpretation of bacterial viability by using the LIVE/DEAD BacLight kit in 
1 combination with flow cytometry. Applied and Environmental Microbiology 2007, 73 (10), $2 \quad 3283-3290$. 